\title{
UK Environmental Accounts
}

Environmental accounts are 'satellite accounts' to the main National Accounts. Satellite accounts are extensions to the National Accounts, which facilitate analysis of the wider impact of economic change. Environmental accounts provide information on the environmental impact of economic activity (in particular on the emissions of pollutants) and on the importance of natural resources to the economy.

Environmental accounts use similar concepts and classifications of industries to those employed in the National Accounts, and they reflect the recommended European Union and United Nations frameworks for developing such accounts.

The accounts are used to inform sustainable development policy, to model impacts of fiscal or monetary measures and to evaluate the environmental performance of different industrial sectors.
Most data are provided in units of physical measurement (volume or mass), although where appropriate some accounts are shown in monetary units.

This chapter includes information previously published in the 2009 edition of Environmental Accounts ${ }^{1}$ and updates information on environmental taxes. More detailed information on each of these accounts is available in UK Environmental Accounts on the ONS website:

www.statistics.gov.uk/statbase/Product.asp?vlnk=3698

The diagram below shows how the areas covered by environmental accounts relate to the economy as described by the National Accounts.

\section{Environment and economy interactions}

Physical inputs

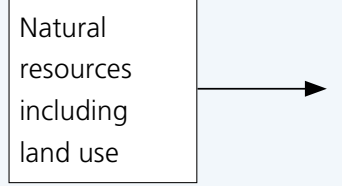

Domestic economic activity

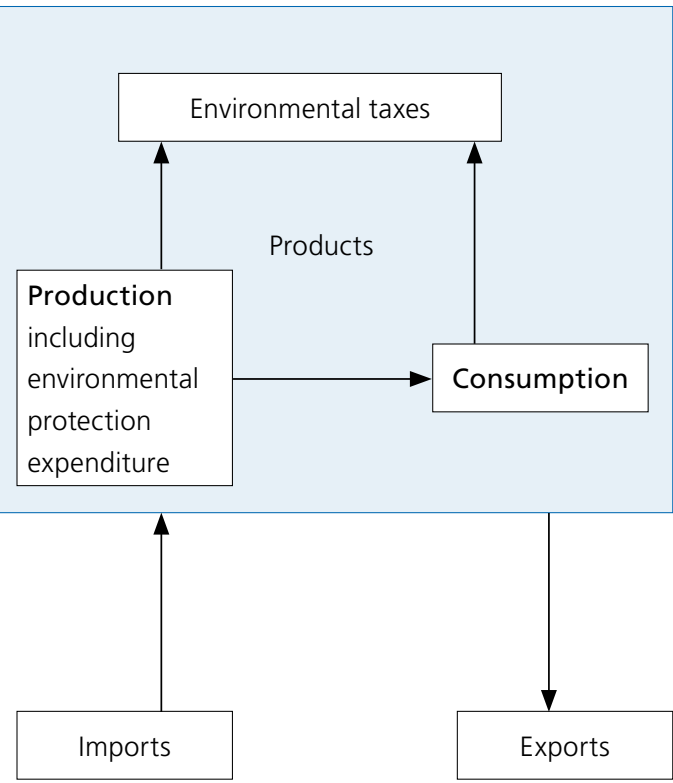

Physical outputs

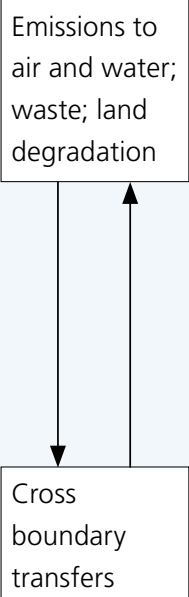




\section{Oil and gas reserves (Tables 13.1 and 13.2)}

\section{Definition of oil and gas}

Oil reserves include both oil and the liquids and liquefied products obtained from gas fields, gas-condensate fields and from the associated gas in oil fields. Gas reserves are the quantity of gas expected to be available for sale from dry gas fields, gas-condensate fields and oil fields with associated gas. Gas which is expected to be flared or used offshore is not included.

This publication uses terminology introduced by the Department for Energy and Climate Change (DECC) to describe UK reserves of oil and gas. ${ }^{2}$ Descriptions are now more closely aligned to those used by the oil and gas industry in order to improve general understanding and ensure consistency. Reserves are classified into the following categories: reserves, potential additional reserves and undiscovered resources. Undiscovered resources relate to those resources as yet undiscovered but potentially recoverable in mapped leads. Potential additional reserves are defined as discovered reserves that are not currently technically or economically producible. Reserves are classified as discovered, remaining reserves which are recoverable and commercial. These can be subdivided into proven, probable or possible depending on confidence level.

Simulation models using Monte Carlo techniques have been used each year by DECC to assess the likely existence and size of undiscovered oil and gas fields on the UK Continental Shelf (UKCS). The assessments are presented as ranges, but the limits of the ranges should not be regarded as maxima or minima. Estimates of the volume of undiscovered reserves have fluctuated considerably in recent years as new areas of UKCS have been subjected to statistical analysis and older areas have been re-assessed.

The lower end of the range of total reserves shown in the table is the sum of estimated proven reserves and the lower end of the range of undiscovered resources for that year, net of cumulative production.

The upper end of the range of total reserves is the sum of estimated proven, possible and probable reserves, plus the upper end range of undiscovered resources, for that year, net of cumulative production.

The expected level of reserves is calculated as the sum of proven and probable reserves and the lower end of the range of undiscovered resources.

Other volume changes are calculated as the difference between the expected level of reserves at the start of the year, less production within that year, and the estimated level of reserves at the start of the following year.

\section{Monetary valuation of oil and gas reserves}

Expressing UK oil and gas reserves in monetary terms allows these subsoil assets to be compared with other economic entities. This provides a means for the commercial depletion of subsoil assets to be set against national income. Results are presented in Table 13.2 in the form of a balance sheet.

Since observed market values for transactions in situ in their original state are not widely available, the present value method is used to put a monetary value on the physical stocks of assets. This is an indirect valuation method measuring the current value of the asset's future streams of income by discounting the expected future rent, often referred to as the economic rent or resource rent. The method relies on information about the size of resource rent, the number of years for which the rent is to be received and the social discount rate to be applied.

The resource rent is the net income from extraction defined as total revenue from sales less all costs incurred in the extraction process, that is, operating costs, depreciation of capital and an allowance for the return on capital. Decommissioning costs have not been included in these accounts. The rate of return on capital is estimated to be 8 per cent in real terms, in line with Eurostat recommendations ${ }^{3}$, but it is worth noting that the resulting valuations are very sensitive to variations in this estimate. A three point centred moving average is used for the calculation of the unit resource rent.

The time span until the complete exhaustion of the reserves is the period over which resource rents are discounted, using the Eurostat recommended social discount rate of 4 per cent. Using these assumptions it is possible to calculate a present value of the stocks of oil and gas reserves at the start and end of each year. The accumulation account then breaks down the change between the start-of-year balance and the end-of-year balance. While physical stocks may change only as a result of extraction and other volume changes such as reassessments, monetary stocks can change for a number of other reasons.

Extraction is equal to the total resource rent for the year, effectively reducing the present value of the stocks by that amount. Positive values for extraction are a result of estimated negative resource rents. Revaluation due to time passing takes account of the fact that, as we move forward in time, the period over which the future rents are discounted is one year less, thereby reducing the effect of discounting future incomes. Other volume changes are reassessments which change the estimated physical stock of recoverable reserves.

The change in the extraction path sets out in monetary terms the addition or subtraction to the present value arising from a change in the amounts assumed to be extracted each year. 
The change in unit rent gives the change in the future stream of income resulting from a change in the estimated unit resource rent. Any negative stock values result from estimated negative resource rents and have been left in the table in order to show he results of the assumptions made in the calculation.

\section{Energy consumption (Table 13.3)}

The Energy Consumption dataset gives estimates of total energy used by each industry and the proportion of total energy used from renewable resources. Detailed estimates of consumption of different fuel types by each sub-sector are given on the ONS website:

\section{www.statistics.gov.uk/statbase/Product.asp?vlnk=3698}

\section{Unit of measurement}

The unit of measurement is tonne of oil equivalent (toe), which enables different fuels to be compared and aggregated. It should be regarded as a measure of energy content rather than a physical quantity. Standard conversion factors for each type of fuel are given in the Digest of UK Energy Statistics (DUKES) ${ }^{4}$.

Consumption of carbon fuels, energy used in transformation processes and losses in distribution

The consumption of carbon fuels, and the related consumption of energy, can be analysed from a number of different perspectives. In terms of atmospheric emissions, it may be helpful to identify which sectors are actually consuming the carbon fuels that give rise to emissions. From this perspective, fuels used by the electricity generation sector are attributed entirely to that sector, even though some of the energy is transformed into electricity. This analysis is shown in Part 1 of the table showing Energy Consumption.

In terms of energy consumption, it is possible to attribute energy used during the process of transformation into electricity, and the energy lost in distributing electricity to end users, either directly to the electricity generation sector, or indirectly to the consumers of energy. Parts 2 and 3 of the table in Energy Consumption consider energy consumption from both points of view. Part 2 allocates the consumption of energy directly to the immediate consumer of the energy, while Part 3 allocates these 'electricity overheads' of the major power producers to the user of the electricity.

Non-energy uses of fuels

Non-energy use of fuels includes, for example, chemical feedstocks, solvents, lubricants and road-making material. These uses have been excluded from the data.

\section{Renewable energy sources}

Renewable energy is defined to include solar power, energy from wind, wave and tide, hydroelectricity, and energy from wood, straw and sewage gas. Landfill gas and municipal solid waste combustion have been included with renewable energy for the purposes of defining energy sources in the context of sustainable development policy.

Sources and methods for estimating consumption of energy by industrial sector

Data for estimating fuel consumption by industrial sectors are collected by DECC and are published in DUKES. However, the figures shown in Energy Consumption differ from those given in DUKES in that:

- Fuels used by the UK fishing fleet, UK international shipping and aircraft operators and ships and aircraft used for UK military purposes are included, whether or not they were purchased in the UK, whereas fuels purchased in the UK by non-resident operators are excluded

- Purchases of petrol and diesel abroad by UK motorists and road hauliers are included

- Non-energy uses of fuels for example, chemical feedstocks, solvents, lubricants and road-making material, are excluded. However, energy lost through gas leakage etc is included

- The classification of industrial sectors used in environmental accounts differs from that used in DUKES. In particular, the transport sector is defined to include only enterprises that provide transport services to other consumers (that is, public transport operators, freight haulage companies, etc). The energy consumed by households' use of private cars is allocated to the domestic sector

For the first time, the 2009 Environmental Accounts publication ${ }^{1}$ includes a bridging table, quantifying these differences.

The allocation of energy use to particular industries is primarily based on DUKES data. However, for certain industries better estimates are used as published by DECC in Energy Trends. Differences in publication times may result in minor reconciliation anomalies between ONS and DECC energy data.

\section{Atmospheric emissions (Tables 13.4 and 13.5)}

Tables 13.4 and 13.5 give estimates of pollutants directly emitted to the atmosphere by each sector. The figures are on a National Accounts basis and differ from the basis used to monitor progress against the Kyoto Protocol in that they include estimated emissions from fuels purchased abroad by UK residents ${ }^{5}$, including those used by international shipping and aircraft on international flights. Emissions from fuels purchased in the UK by non-UK residents are excluded. Detailed estimates of pollutants from each sub-sector are 
given on the ONS website:

www.statistics.gov.uk/statbase/Product.asp?vlnk=3698.

The website also gives details of emissions from acid rain precursors such as Sulphur Dioxide, other pollutants like Benzene and heavy metals including Lead and Zinc.

\section{Pollutants and environmental themes}

Atmospheric emissions can be aggregated according to their contribution to environmental themes such as greenhouse gases and acid rain. A description of the pollutants covered and the methodology used to calculate environmental themes is given in the annex to these notes.

\section{Attributing emissions to industrial sectors}

The disaggregation of national estimates of emissions to industrial sectors is based upon an initial disaggregation provided by the National Environmental Technology Centre (AEA Energy and Environment) ${ }^{6}$ which maintains the National Atmospheric Emissions Inventory (NAEI) ${ }^{7}$. Emissions are estimated by multiplying fuel consumption by emissions factors and adding releases unrelated to fuel use such as methane arising from landfill.

The NAEI data is used to identify the main processes and industries responsible for the emissions, which are then allocated to individual sectors on the basis of information from a variety of sources. For example, emissions from diesel use by Heavy Goods Vehicles are allocated to sectors using vehicle mileage data from the Department for Transport. Expenditure information is also used, for example to allocate emissions arising from the use of various industrial coatings (for example, general industrial, heavy duty and vehicle refinishing) to relevant sectors in proportion to each sector's expenditure on paints, varnishes and similar coatings, printing ink and mastics, using the National Accounts supply-use tables as the main source. A full description of the methods and sources used in these accounts is available on request from the ONS Environmental Accounts branch.

There are a number of formats for the reporting and recording of atmospheric emissions data. These include the Intergovernmental Panel on Climate Change (IPCC) and United Nations Economic Commission for Europe (UNECE) measures both published by Defra and the National Accounts consistent measure published by ONS. For further details please refer to Environmental Accounts on the ONS website.

Table 13.4, shows latest estimates of air pollutants directly emitted by each sector. Emissions generated by the electricity supply industry have not been reallocated to their customers in this analysis. Emissions from road haulage are given on an 'own account' basis, that is, attributed to the sector owning the transport rather than to the sector of the goods being transported. Similarly emissions from households' use of private cars are allocated to the domestic sector. Figures for total road transport emissions are provided separately.

Table 13.5 shows estimates of greenhouse gases and acid rain emissions by industrial sector.

\section{Material flows (Table 13.6)}

Material flow accounts record the total mass of natural resources and products that are used by the economy, either directly in the production and distribution of products and services, or indirectly through the movement of materials which are displaced in order for production to take place.

A material flow account balances the inputs (extraction of natural resources from the UK environment, and imports of goods) with the outputs (wastes, emissions to air and water, exports) and accumulation (in terms of new buildings, etc) within the economy.

The direct input of materials into the economy derives primarily from domestic extraction, that is, from biomass (agricultural harvest, timber, fish and animal grazing), fossil fuel extraction (such as coal, crude oil and natural gas) and mineral extraction (metal ores, industrial minerals such as pottery clay, and construction material such as crushed rock, sand and gravel).

The direct input of materials from domestic sources is supplemented by the imports of products, which may be of raw materials such as unprocessed agricultural products, but can also be semi-manufactured or finished products. In a similar way the UK exports of raw materials, semimanufactured and finished goods which can be viewed as inputs to the production and consumption of overseas economies.

Water is used so widely and in such quantities that its inclusion in the accounts tends to obscure other resource use. For this reason, the accounts only include the water that is contained in products (for example, agricultural produce and imported beverages). Water for other consumptive uses (cleaning or irrigation) and in situ uses (such as hydroelectric power) is excluded from these accounts.

Hidden flows measure the quantity of material displaced by the process of extraction but not actually used in the production of goods and services. Indirect flows measure the quantity of material associated with imports of raw and semi-processed goods into the UK. Both hidden and indirect flows are measured indirectly by applying coefficients for particular materials and goods to the estimated levels of mass associated with domestic and overseas extraction. Therefore, there is a direct relationship between hidden flows and actual extraction. Levels are sensitive to assumptions embodied in the particular 
hidden or indirect flow coefficient used. Examples of hidden flows are unused extraction from mining and quarrying (also known as overburden), discarded material from harvesting (for example, wood harvesting losses such as timber felled but left in the forests), and soil and rock moved as a result of construction and dredging.

\section{Indicators}

There are a number of indicators which can be used to summarise the flows of materials into and out of the economy. Material flows show three of the main indicators used to measure inputs.

Direct Material Input (DMI) measures the input of materials directly used by the economy. It is the sum of domestic extraction and imports less exports.

Domestic material consumption (DMC) measures the total amount of material directly consumed by the economy. It is the sum of domestic extraction and imports less exports.

The Total Material Requirement (TMR) measures the total material basis of the economy, that is the total direct and indirect resource requirements of all the production and consumption activities. TMR includes the amount of used extraction in the UK, the imports into the UK and the resulting indirect or hidden flows associated with extraction in the UK and imports from other countries. Although TMR is widely favoured as a resource use indicator, the estimates of indirect flows are less reliable than those for materials directly used by the economy, and it can be argued that it double-counts trade flows, in that materials used both in the production of imports and in the production of exports are included. The indicator therefore needs to be considered alongside other indicators.

The Physical Trade Balance (PTB) measures the difference between the total mass of exports and the total mass of imports. This can be used to understand the internal relationship of material use in the UK.

\section{Sources and methods}

Data on the yields of agriculture, forestry and fishing come from the Food and Agriculture Organization (FAO) ${ }^{8}$. Mineral extraction data have been taken from the UK Minerals Yearbook ${ }^{9}$ and information on the mass of imports and exports has been taken from trade information compiled by HM Revenue and Customs ${ }^{10}$.

Factors applied to give estimates of the amounts of unused material moved for each tonne of used material have been taken from research carried out by the Wuppertal Institute on behalf of the Department for Environment, Food and Rural Affairs (Defra) ${ }^{11}$. The methodology used to compile the account is also based upon the Wuppertal Institute's research.

\section{Government revenues from environmental taxes (Table 13.7)}

The environmental taxes table shows the level of revenues raised in environmental taxes in the United Kingdom.

\section{Definition of an environmental tax}

An environmental tax is defined as a tax whose base is a physical unit such as a litre of petrol, or a proxy for it, for instance a passenger flight, that has a proven specific negative impact on the environment. By convention, in addition to pollution related taxes, all energy and transport taxes are classified as environmental taxes. This definition has been agreed by international experts and adopted by the Statistical Office of the European Communities (Eurostat) and Organisation for Economic Co-operation and Development (OECD). It enables analysis to be based on the effects of taxes rather than the aims behind their introduction, that is, the aim of a tax for raising government revenue rather than reducing environmental degradation does not preclude it from being defined as an environmental tax.

Nevertheless, the interpretation and use of measures of environmental taxes need care. In particular, the levels of revenues from environmental taxes do not necessarily indicate the relative importance or the success of environmental policy. High environmental tax revenues can result either from high rates of taxes or from high levels of environmental problems (for example, pollution) leading to a large tax base. The broad measure of revenues can also fail to capture the effect of the differential rates that encourage a shift away from higher impact behaviour (such as the use of leaded petrol).

Taxes on energy products include duties on hydrocarbon oils used in road vehicles, the main ones being ultra low sulphur petrol and ultra low sulphur diesel. Taxes on energy products also include those used for non-transport purposes (such as industrial gas turbines and heating installations, with a reduced rate for energy saving materials) and the fossil fuel levy, which is levied on sales of electricity from fossil fuels and was used to compensate companies producing electricity from non-fossil fuel sources such as nuclear or renewable energy.

The climate change levy, which is a tax on non-domestic use of energy, was introduced in April 2001. The levy applies to the suppliers of the following energy types: electricity, natural gas as supplied by a gas utility, petroleum and hydrocarbon gas in a liquid state, coal and lignite, coke and seem-coke of coal or lignite, and petroleum coke.. The rates of the levy are based on the type and quantity of fuel supplied, with a range of relief and exemptions available.

VAT on duty is calculated as a fixed proportion, in most cases 17.5 per cent (15 per cent from December 2008) of the duty paid 
on hydrocarbon oils. In practice much of this VAT will be reclaimed by business, but it could be argued that the total will eventually be paid when the final product or service is purchased.

Taxes on road vehicles include Vehicle Excise Duty, which keepers of motor vehicles can pay on either a six monthly or annual basis. There have been various changes to this duty over recent years. As from 1 May 2002, private cars, taxis and light goods vehicles registered before 1 March 2001 with an engine size up to and including $1549 \mathrm{cc}$ are subject to a lower tax than cars with engine sizes greater than $1549 \mathrm{cc}$. The same vehicle types registered on or after 1 March 2001 are taxed according to the level of carbon dioxide emissions. This is now presented broken down by payments from businesses and households. Car tax was payable on purchases of new cars up until 1993 when it was discontinued.

Hydrobenefit was introduced in 1991 to protect energy consumers in remote areas, especially the Scottish Highlands and Islands, from excessive charges resulting from the increased costs involved in supplying those areas. The scheme was abolished in 2004 though it continued until April 2005 on a voluntary basis.

Air passenger duty was introduced on 1 November 1994. It applies to the carriage from a UK airport of chargeable passengers on chargeable aircraft at two different rates. The lower rate is charged where passengers are travelling to a UK destination or within the European Economic Area (EEA), and the higher rate applies in all other cases. On the year of introduction, the lower and higher rates of duty were $\mathrm{f} 5$ and $\mathrm{f} 10$ respectively. From 1 April 2007, standard rates of $\mathrm{f} 20$ for EEA destinations and $\mathrm{f} 80$ for other destinations have been applied. There are also reduced rates of duty for the lowest class of travel on any flights.

Landfill tax was introduced in October 1996 and aims to encourage waste producers to produce less waste, recover more value from waste, for example, through recycling or composting and to use more environmentally friendly methods of waste disposal. The tax applies to active and inactive (inert) waste disposed of at landfill sites. Generally when waste is committed to landfill it undergoes physical chemical or biological transformations which then react with surrounding matter. Known as leaching, this process can give rise to environmental damage and harm human health. Waste classified as inactive has insignificant levels of leachability, pollutant content and ecotoxicity. Types of waste excluded from this tax include dredgings, disposals from mines and quarries and also waste resulting from the clearance of contaminated land. A standard rate of tax is levied on active waste, this was introduced at the rate of $f 7.00$ per tonne and has since risen to $\mathrm{f} 14.00$ per tonne in 2003-04. this rate will subsequently be increased each year until it reaches a medium to long term rate of $£ 35.00$ per tonne. A lower rate of tax is levied on inert waste, which has remained at $\mathrm{f2.00}$ per tonne from the year of introduction.

The aggregates levy was introduced on 1 April 2002. The objective of this tax is to address the environmental costs associated with quarrying operations (noise, dust, visual intrusion, loss of amenity and loss to biodiversity), by reducing the demand for aggregate and encouraging the use of alternative materials where possible, for example, the use of waste glass and tyres in aggregate mixes. The tax applies to the commercial exploitation of sand, gravel and rock and includes aggregate dredged from the seabed within UK territorial waters. It is a specific tax, charged at $\mathrm{f1.60}$ per tonne.

There is a wide range of exemptions for some quarried or mined products, for example, coal, metal ores, industrial minerals and for minerals used in the production of lime and cement and for exports of aggregates. Imports of aggregates are taxed upon first sale or use in the UK.

\section{Environmental taxes breakdown by 13 industries (Table 13.8)}

The environmental taxes breakdown by 13 industries is based on general government environmental taxes data and unpublished Supply-Use data for taxes on products and production that are informed by latest available Supply-Use tables. From these sources it is possible to estimate allocations of environmental taxes to individual industries. A more detailed account of the methods used in this analysis is published on the ONS website at www.statistics.gov.uk/statbase/product.asp?vInk $=11041 .{ }^{16}$

\section{Environmental protection expenditure (Tables 13.9 and 13.10)}

Estimates of environmental protection expenditure should be regarded as approximate orders of magnitude only. Because of this qualification, the estimates shown fall outside the scope of National Statistics.

\section{Comparisons with previous surveys}

The information on spending by industries in 2006, which is summarised in environmental protection expenditure in specified industries, 2006 comes from a regular series of surveys conducted by the URS Corporation on behalf of Defra. The estimates from this survey and the earlier surveys should be regarded as very approximate and any comparisons between the results should be treated with care.

\section{Definition of expenditure}

Environmental protection expenditure is defined as capital and operational expenditure incurred because of, and which can be 
directly related to, the pursuit of an environmental objective. Spending on installations and processes which are environmentally beneficial, but which also produce revenue (or savings) exceeding expenditures, are excluded on the grounds that they are likely to have been carried out for commercial not environmental reasons. Also excluded are expenditures on natural resource management (for example, fisheries and water resources), on the prevention of natural hazards (for example, flood defence), on the provision of access and amenities to National Parks etc, and on the urban environment. The spending has been classified by the following groups of environmental concerns:

- Protection of ambient air and climate

- Waste water management

- Waste management

- Protection of biodiversity and landscapes

- Other abatement activities such as on the protection of soil and groundwater, protection against radiation, and noise and vibration abatement

- Other environmental expenditure, on research and development, education and administration

The spending shown in 2004 public sector environmental protection expenditure has also been classified by the following types of expenditure:

- current costs, including staff costs (compensation of employees), other on-going expenditure on purchases of goods and services and the estimated consumption of fixed capital

- capital expenditure or investment including outlays on land and on the additions of new durable goods to the stock of fixed assets for environmental protection

- income from sales, fees and charges for the provision of current or capital goods and services, such as fees for waste removal, but excluding taxes

- current and capital transfers to other sectors of the economy

- net transfers to and from the Rest of the World, in the form of aid or other grants, net of grants received from the EU

There are five main categories of spending in environmental protection expenditure by specified industries:

- End-of-pipe=investment is defined as add-on installations and equipment which treats or controls emissions or reduces waste material generated by the plan, but which does not affect production processes

- Integrated processes are adaptations or changes to production processes in order to generate fewer emissions or waste materials
- In-house operating expenses cover operating costs necessary to run end-of=pipe or integrated facilities

- Current payments made to others include all payments to third parties for environmental services, including payments for the treatment or removal of solid waste, water service company charges for sewage treatment, payments to contractors for the removal or treatment of waste waters, and payments made to environmental regulatory authorities

- Research and development expenditure includes both in-house research and development and amounts paid to others such as trade associations and consultants.

\section{Sources}

Environmental protection expenditure in specified industries gives figures for spending by the extraction, manufacturing, energy production and water supply industries. They are drawn from a survey for 2006 carried out on behalf of the Department for Environment, Food and Rural Affairs (Defra) by URS Corporation Ltd.

Environmental protection expenditure by the public sector gives estimates for expenditures by the public sector and is based on information obtained from a variety of sources such as the public expenditure database and from various government departments, local authorities and the devolved administrations.

Data for industry and public sector environmental protection expenditure should not be added together as differing classification procedures make comparisons problematic

\section{Annex: Atmospheric pollutants and environmental themes}

\section{Greenhouse gases}

There is a growing consensus that the rise in concentrations of greenhouse gases in the atmosphere has led to changes in the global climate system. The greenhouse gases included in the atmospheric emissions accounts are those covered by the Kyoto Protocol: carbon dioxide $\left(\mathrm{CO}_{2}\right)$, methane $\left(\mathrm{CH}_{4}\right)$, nitrous oxide $\left(\mathrm{N}_{2} \mathrm{O}\right)$, hydrofluorocarbons (HFCs), perfluorocarbons (PFCs) and sulphur hexafluoride $\left(\mathrm{SF}_{6}\right)$.

Carbon dioxide $\left(\mathrm{CO}_{2}\right)$ emissions mainly come from the combustion of fossil fuels, but it is also produced in some industrial processes such as the manufacture of cement. Carbon dioxide is a long-lived gas remaining in the atmosphere for between 50 and 200 years. It is the main anthropogenic greenhouse gas.

Methane $\left(\mathrm{CH}_{4}\right)$ is produced when organic matter is broken down in the absence of oxygen. Large quantities are produced by enteric fermentation in cattle and sheep, by the spreading of animal manure and from organic waste deposited in landfill 
sites. Methane is also emitted in coal mining, oil and gas extraction and gas distribution activities. Methane is a significant greenhouse gas.

Nitrous oxide $\left(\mathrm{N}_{2} \mathrm{O}\right)$ is released in a few industrial processes and from the soil when nitrogenous fertilisers are applied in agriculture and horticulture. It is a long-lived pollutant, lasting about 120 years in the atmosphere and is a potent greenhouse gas.

Hydrofluorocarbons (HFCs), perfluorocarbons (PFCs) and sulphur hexafluoride $\left(\mathrm{SF}_{6}\right)$ are artificial fluids that contain chlorine and/or fluorine. Because of their low reactivity and non-toxicity they were widely used as refrigerants, foam blowing agents, aerosol propellants and solvents.

To aggregate the greenhouse gases covered in the accounts, a weighting based on the relative global warming potential (GWP) of each of the gases is applied, using the effect of $\mathrm{CO}_{2}$ over a 100 year period as a reference. This gives methane a weight of 21 relative to $\mathrm{CO}_{2}$ and nitrous oxide a weight of 310 relative to $\mathrm{CO}_{2} . \mathrm{SF}_{6}$ has a GWP of 23,900 relative to $\mathrm{CO}_{2}$. The GWP of the other fluorinated compounds varies according to the individual gas.

Greenhouse gas emissions are sometimes shown in terms of carbon equivalent rather than $\mathrm{CO}_{2}$ equivalent. To convert from $\mathrm{CO}_{2}$ equivalent to carbon equivalent it is necessary to multiply by $12 / 44$.

\section{Acid rain precursors}

The term 'acid rain' describes the various chemical reactions which acidic gases and particles undergo in the atmosphere. The gases may be transported long distances before being deposited as wet or dry deposition. When deposited, hydrogen ions may be released, forming dilute acids, which damage ecosystems and buildings. The gases covered are sulphur dioxide $\left(\mathrm{SO}_{2}\right)$, nitrogen oxides $\left(\mathrm{NO}_{\mathrm{x}}\right)$ and ammonia $\left(\mathrm{NH}_{3}\right)$.

The emissions are weighted together using their relative acidifying effects. The weights, given relative to $\mathrm{SO}_{2}$, are 0.7 for $\mathrm{NO}_{x}$ and 1.9 for $\mathrm{NH}_{3}$. This is a simplification of the chemistry involved, and there are a number of factors which can affect the eventual deposition and effect of acid rain. There may be an upward bias on the weights of the nitrogenbased compounds in terms of damage to ecosystems.

Sulphur dioxide $\left(\mathrm{SO}_{2}\right)$ is produced when coal and some petroleum products containing sulphur impurities are burnt. Sulphur dioxide is an acid gas that can cause respiratory irritation. It can damage ecosystems and buildings directly and is a major contributor to acid rain.

Nitrogen oxides $\left(\mathrm{NO}_{\mathrm{x}}\right)$ arise when fossil fuels are burnt under certain conditions. High concentrations are harmful to health and reduce plant growth. Like sulphur dioxide, nitrogen oxides contribute to acid rain; nitrogen dioxide $\left(\mathrm{NO}_{2}\right)$ also plays a part in the formation of ground ozone layer.

Ammonia $\left(\mathrm{NH}_{3}\right)$ is predominantly emitted from spreading animal manure and some fertilisers.

\section{Other air pollutants}

$\mathrm{PM}_{10} \mathrm{~s}$ are smoke particles whose diameter is less than ten microns. They are regarded as responsible for some physiological damage and have been linked to premature mortality from respiratory diseases.

Carbon monoxide (CO) is produced in small quantities when fossil fuel is burnt with insufficient oxygen for complete combustion. At high concentrations carbon monoxide is toxic.

\section{Non-methane volatile organic compounds (NMVOCs)} cover a variety of chemicals, many of which are known carcinogens. Emissions of NMVOCs arise from the deliberate and incidental evaporation of solvents (e.g. in paints and cleaning products), from accidental spillage and from non-combustion of petroleum products. The environmental accounts include natural emissions of NMVOCs from managed forests. NMVOCs play a role in the formation of ground level ozone, which can have an adverse effect on health. The NMVOC emissions include benzene and 1,3-butadiene.

Benzene is released largely from the distribution and combustion of petrol. It is a carcinogen which has also been found to cause bone-marrow depression and consequent leukopenia (depressed white blood cell count) on prolonged exposure.

1,3-Butadiene is a colourless, gaseous hydrocarbon. It is produced by dehydrogenation of butene, or of mixtures of butene and butane; it may also be made from ethanol. 1,3-butadiene is believed to be a carcinogen, for which the safe level is not known. Emissions of 1,3-butadiene arise from combustion of petroleum products and in its manufacture of synthetic rubber, nylon and latex paints in the chemical industry. 1,3-butadiene is not present in petrol but is formed as a by-product of combustion. The increasing use of catalytic converters through the 1990s has caused a significant reduction in emissions from the road transport sector.

\section{Heavy Metals}

Lead $(\mathrm{Pb})$ is a heavy metal that is emitted from the combustion of petrol, coal combustion and metal works. Emissions of lead continued to fall in 2000, mainly as a result of the ban on the sale of leaded petrol from 1 January 2000. Lead has been found to inhibit the development of children's intelligence. If the levels of lead are sufficient, lead can cause degenerative processes such as osteoporosis, inhibit many 
enzyme reactions in the body and cause reproductive disorders such as sterility and miscarriages.

Cadmium (Cd) is a normal constituent of soil and water at low concentrations. Industrially, cadmium is used as an anti-friction agent, in alloys, semi-conductors, control rods for nuclear reactors and PVC and battery manufacture. The main sources of cadmium emissions are from waste incineration, and iron and steel manufacture. Emissions of cadmium have declined over recent years; this is mainly attributable to the decline in coal combustion.

Environmentally, cadmium is dangerous because many plants and some animals absorb it easily and concentrate it in tissues. Cadmium competes with calcium in the body, and if levels are sufficient, it will displace calcium, causing embrittlement of bones and painful deformations of the skeleton. Cadmium also competes with zinc in the body, and if levels of cadmium are high enough, cadmium will also displace zinc from enzymes in the body.

Mercury $(\mathrm{Hg})$ emissions are generated by waste incineration, the manufacture of chlorine in mercury cells, non-ferrous metal production and coal combustion. Emissions of mercury have declined over recent years due to improved controls on mercury cells and their replacement by diaphragm cells and the decline of coal use. Due to the volatility of mercury, if levels are sufficiently high, compounds containing mercury attack and destroy various parts of the body, particularly teeth, lung tissues and intestines.

\section{References}

1 Office for National Statistics (2009) Environmental Accounts Spring 2009 edition.

www.statistics.gov.uk/statbase/Product.asp?vlnk=3698

2 Department for Energy and Climate Change Oil and Gas website.

www.og.berr.gov.uk/information/index.htm

3 European Commission (2000) Accounts for subsoil assets: Results of pilot studies in European countries, 2000. Office for Official Publication of the European Communities, Luxembourg

4 Department for Energy and Climate Change. Digest of United Kingdom Energy Statistics. Various issues, HMSO/TSO.

www.berr.gov.uk/whatwedo/energy/statistics/ publications/dukes/page45537.html

5 Office for National Statistics (2002). Adjustments to the UK's atmospheric emissions and energy accounts to bring them on to a National Accounts 'Residents' basis. Report to Eurostat, April 2002.

www.statistics.gov.uk/downloads/theme environment/Adjustments_UK_atmospheric_ emissions_energy_accounts_national_accounts_ residents_basis.pdf

6 AEA Energy and Environment. www.airquality.co.uk/archive/index.php

7 Department for Environment, Food and Rural Affairs. www.defra.gov.uk/environment/statistics/globatmos/ gagccukem.htm

8 Food and Agricultural Organization (FAO). www.fao.org/

9 British Geological Survey (2008) UK Minerals Yearbook 2007. www.bgs.ac.uk/mineralsuk/commodity/uk/ukmy.html

10 HM Revenue and Customs trade data. www.uktradeinfo.com

11 Department for Environment, Food and Rural Affairs (Defra) Resource Use and Efficiency of the UK Economy: A study by the Wuppertal Institute.

12 Office for National Statistics (2003) UK Material Flows Review.

www.statistics.gov.uk/statbase/Product.asp?vlnk=3698

13 Office for National Statistics (2002) Economic Trends No. 583 (June 2002) UK Material Flow Accounting. www.statistics.gov.uk/CCl/article.asp?ID=140

14 Office for National Statistics (2005) Economic Trends No. 619 (June 2005) Flows between 1970-2003. www.statistics.gov.uk/cci/article.asp?ID =1174

15 Office for National Statistics (2006) Economic Trends No. 635 (October 2006) UK environmental taxes: classification and recent trends.

www.statistics.gov.uk/CCl/article.asp?ID $=1650 \&$ Pos $=1 \&$ ColRank=1\&Rank=224

16 Office for National Statistics (2004) Economic Trends No. 609 (August 2004), An Industrial Analysis of Environmental Taxes.

www.statistics.gov.uk/statbase/product.asp?vlnk=11041

17 URS Dames and Moore (2007) Environmental Protection Expenditure by Industry: 2006 UK Survey. [June] 2008. www.defra.gov.uk/environment/statistics/envsurvey/ index.htm 


\begin{tabular}{llllllllll}
1998 & 1999 & 2000 & 2001 & 2002 & 2003 & 2004 & 2005 & 2006 & 2007 \\
\hline
\end{tabular}

Oil (Million tonnes)

\section{Reserves}

Proven
Probable
Proven plus Probable
Possible
Maximum

Range of undiscovered resources

Lower

Upper

Range of total reserves

Lower $^{1}$

Upper $^{2}$

Expected level of reserves ${ }^{3}$

Opening stocks

Extraction ${ }^{4}$

Other volume changes

Closing stocks

685
575
1260
540
1800

665
455

455
1120

1120
545

1800

1665

JKOZ

JKNY

JKNZ

275

2550

250
2600

2600

225
2300

630

380
1010

1010
480

1490

605
350
955

475
1430

593
327
920
425
134

571
286
857
410
1267

533

283

816

512

1328

$\begin{array}{rrr}516 & 479 & 452 \\ 300 & 298 & 328 \\ 816 & 776 & 780 \\ 451 & 478 & 399 \\ 1267 & 1254 & 1179\end{array}$

1267

1254

1179
960

915
4265

855
3790

810
3360

865
3115

894

929
3158

862
2848

917
2892

831

1675

$1675 \quad 1535$

1370

1235

1160

1192

JKOD

JKOE

JKOF
$-126$

$-117$

$-117$

149

1192

Gas (billion cubic metres)

\section{Reserves}

Proven

Probable

Proven plus Probable

Possible

Maximum

Range of undiscovered resources

Lower

Upper

JKOM

Range of total reserves

Lower $^{1}$

Upper $^{2}$

JKOO

JKOP

Expected level of reserves ${ }^{3}$

Opening stocks

Extraction ${ }^{4}$

Other volume changes

Closing stocks

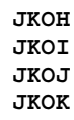

JKOQ
JKOR
JKOS
JKOT
755

585
1340

760

500
1260

$455 \quad 490$

$1795 \quad 1750$

735

460
1195

695

445
1140

$430 \quad 395$

$1630 \quad 1535$

628

369

998

331

1329

590

315

905

336

531
296

296
826

343

1169

481
247

247
728

278

1006

412
272

272
684

283

967

343

304
647

293

940

440

440
1595

355

325

290

238

279

293

226

301

280

$1195 \quad 1115$

1195
339

1115
3215

1060

3065

985

321

866

869

869
2500

824

707

2041

713
2016

623

$1885 \quad 1780$
1780
-99
-66

-66
1615

1615

-108
13

1520
1520

1430

1235

1235
-102

51

1184

$1430 \quad 1235$
$1184 \quad 1120$

120
-86

954

-95
31

1120

-80
954

-78
109

985

985

$-71$

13
927

1 The lower end of the range of total reserves has been calculated as the sum of proven reserves and the lower end of the range of undiscovered reserves.

2 The upper end of the range of total reserves is the sum of proven, probable and possible reserves and the upper end of the range of undiscovered reserves.

3 Expected reserves are the sum of proven reserves, probable reserves and the lower end of the range of undiscovered reserves.

4 Negative extraction is shown here for the purposes of the calculation only.

Of itself, extraction should be considered as a positive value. 
Oil and gas monetary balance sheet

\begin{tabular}{|c|c|c|c|c|c|c|c|c|c|c|c|}
\hline & & & & & & & & & & & $\mathrm{f}$ million \\
\hline & & 1998 & 1999 & 2000 & 2001 & 2002 & 2003 & 2004 & 2005 & 2006 & 2007 \\
\hline Oil & & & & & & & & & & & \\
\hline Opening stocks ${ }^{1}$ & JKPA & 19472 & 17725 & 46964 & 53611 & 51812 & 50883 & 53045 & 78536 & 100192 & 120921 \\
\hline Extraction $^{2}$ & JKPB & -2000 & -5928 & -6878 & -6578 & -6326 & -6166 & -8260 & -10034 & -10982 & -16674 \\
\hline Revaluation due to time passing & JKPC & 898 & 2418 & 2735 & 2557 & 2333 & 2524 & 3657 & 4924 & 5610 & 8784 \\
\hline Other volume changes & JKPD & -64 & -735 & -295 & 1467 & 5051 & 3238 & 6103 & 2134 & 8922 & 2190 \\
\hline Change in rent & JKPF & -1179 & 32658 & 11660 & 611 & -3584 & 2283 & 24918 & 26329 & 18282 & 59183 \\
\hline Nominal holding gains & $\mathrm{C} 30 \mathrm{C}$ & 424 & 378 & 567 & 1105 & 1597 & 1574 & 1326 & 1762 & 2581 & 3487 \\
\hline Closing stocks & JKPG & 17725 & 46964 & 53611 & 51812 & 50883 & 53045 & 78536 & 100192 & 120921 & 177891 \\
\hline Gas & & & & & & & & & & & \\
\hline Opening stocks & JKPH & 33706 & 25402 & 30495 & 43011 & 50451 & 46566 & 44250 & 50754 & 65402 & 69439 \\
\hline Extraction $^{2}$ & JKPI & -1988 & -2705 & -4222 & -5048 & -5091 & -4980 & -5632 & -7622 & -7304 & -7019 \\
\hline Other volume changes & JKPK & -135 & -803 & 256 & 359 & -2501 & 1423 & 1025 & -4022 & 5744 & 687 \\
\hline Change in extraction & JKPL & 409 & 1289 & 1335 & -552 & -355 & -37 & -1072 & -1941 & -1256 & -1972 \\
\hline Change in rent & JKPM & -8582 & 5217 & 12636 & 9282 & 42 & -2326 & 8567 & 23596 & 2015 & 1860 \\
\hline Nominal holding gains & СЗОВ & 734 & 541 & 368 & 886 & 1555 & 1440 & 1106 & 1139 & 1685 & 2002 \\
\hline Closing stocks & JKPN & 25402 & 30495 & 43011 & 50451 & 46566 & 44250 & 50754 & 65402 & 69439 & 68340 \\
\hline
\end{tabular}

1 The estimated opening and closing stock values are based on the present value method -see Environmental Accounts on the National Statistics website for more detailed descriptions of the methodology used. The estimates are extremely sensitive to the estimated return to capital and to assumptions about future unit resource rents.

2 Negative extraction is shown here for the purposes of the calculation only.

Of itself, extraction should be considered as a positive value. 
Million tonnes of oil equivalent

\section{Direct use of energy from fossil fuels}

Agriculture
Mining and quarrying
Manufacturing
Electricity, gas and water supply
Construction
Wholesale and retail trade
Transport and communication
Other business services
Public administration
Education, health and social work
Other services
Total non-household
Households
tral use of energy
from fossil fuels
Energy from other sources ${ }^{1}$

Total energy consumption of primary fuels and equivalents

Direct use of energy including electricity

Agriculture

Mining and quarrying

Manufacturing

Electricity, gas and water supply

of which - transformation losses by major producers Construction distribution losses of electricity supply

Wholesale and retail trade

Transport and communication

Other business services

Public administration

Education, health and social work

Other services

Total non-household

Households

Total energy consumption of primary fuels and equivalents

JKOD

JKQE

JKOF

JKQG

JKQH

JKQI

JKQJ

$\mathrm{JKQK}$

JKQL

JKQM

JKQN

JKQO

JKQP

IGK2

JKQQ

JKQR

$\begin{array}{rrrrrrrrrrrrr}2.3 & 2.5 & 2.4 & 2.3 & 2.3 & 2.2 & 2.2 & 2.1 & 2.2 & 2.2 & 2.1 & 2.1 & 2.0 \\ 4.7 & 6.2 & 6.4 & 6.8 & 6.7 & 6.9 & 8.0 & 7.8 & 7.9 & 7.8 & 7.6 & 7.3 & 7.0 \\ 41.4 & 41.5 & 41.5 & 40.7 & 40.6 & 40.2 & 39.0 & 36.9 & 37.3 & 36.5 & 37.1 & 35.3 & 34.0 \\ 56.6 & 51.9 & 49.3 & 51.4 & 51.2 & 54.9 & 57.2 & 56.2 & 58.5 & 59.1 & 59.4 & 61.3 & 61.5 \\ 2.8 & 3.2 & 3.2 & 3.2 & 3.2 & 3.1 & 3.1 & 3.2 & 3.2 & 3.3 & 3.5 & 3.4 & 3.5 \\ 5.5 & 6.2 & 6.0 & 6.2 & 6.5 & 6.5 & 6.1 & 5.8 & 6.0 & 6.2 & 6.0 & 5.8 & 6.0 \\ 21.9 & 25.9 & 26.4 & 27.7 & 27.6 & 28.6 & 30.0 & 30.1 & 31.1 & 32.8 & 33.8 & 31.6 & 31.4 \\ 2.6 & 3.0 & 2.8 & 2.8 & 2.9 & 2.9 & 3.0 & 2.5 & 2.6 & 2.5 & 2.6 & 2.5 & 2.5 \\ 3.8 & 4.0 & 3.9 & 3.6 & 3.5 & 3.3 & 3.5 & 3.6 & 3.4 & 3.4 & 3.4 & 3.3 & 3.4 \\ 4.0 & 4.3 & 4.4 & 4.3 & 4.4 & 4.3 & 4.3 & 3.5 & 3.6 & 3.9 & 3.8 & 3.7 & 3.5 \\ 1.9 & 2.0 & 1.9 & 1.9 & 1.9 & 1.9 & 2.0 & 1.7 & 1.8 & 1.8 & 1.8 & 1.8 & 1.7\end{array}$

$\begin{array}{lllllllllllll}147.5 & 150.6 & 148.2 & 150.9 & 150.8 & 154.8 & 158.4 & 153.6 & 157.6 & 159.5 & 160.8 & 158.0 & 156.4\end{array}$

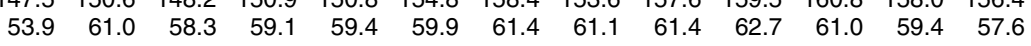

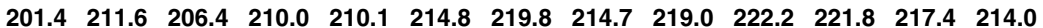
$\begin{array}{lllllllllllll}17.7 & 24.0 & 23.8 & 25.0 & 24.0 & 21.4 & 22.1 & 21.3 & 20.6 & 19.4 & 19.8 & 18.5 & 15.4\end{array}$

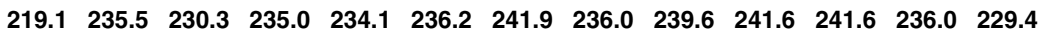

$\begin{array}{rrrrrrrrrrrrr}2.7 & 2.8 & 2.7 & 2.7 & 2.7 & 2.6 & 2.5 & 2.5 & 2.6 & 2.5 & 2.5 & 2.4 & 2.3 \\ 4.9 & 6.4 & 6.5 & 7.0 & 6.9 & 7.1 & 8.2 & 8.0 & 8.1 & 8.0 & 7.8 & 7.6 & 7.2 \\ 48.8 & 49.1 & 48.9 & 48.0 & 48.1 & 47.5 & 46.0 & 44.4 & 44.9 & 44.0 & 44.5 & 42.8 & 41.4 \\ 51.4 & 50.8 & 48.2 & 51.3 & 49.7 & 50.6 & 53.3 & 51.3 & 52.4 & 52.0 & 52.3 & 53.0 & 50.5 \\ 46.5 & 45.2 & 44.0 & 45.3 & 43.7 & 44.0 & 46.3 & 44.9 & 46.4 & 45.6 & 46.6 & 47.4 & 44.8 \\ 2.1 & 2.4 & 2.5 & 2.4 & 2.4 & 2.5 & 2.7 & 2.6 & 2.6 & 2.6 & 2.4 & 2.4 & 2.3 \\ 2.9 & 3.3 & 3.3 & 3.3 & 3.3 & 3.3 & 3.3 & 3.3 & 3.4 & 3.5 & 3.6 & 3.6 & 3.7 \\ 7.4 & 8.6 & 8.6 & 8.7 & 9.1 & 9.2 & 8.9 & 8.7 & 8.9 & 9.2 & 9.0 & 8.8 & 9.0 \\ 22.5 & 26.9 & 27.4 & 28.7 & 28.6 & 29.6 & 31.0 & 31.1 & 32.3 & 33.8 & 35.0 & 32.7 & 32.5 \\ 4.4 & 4.9 & 4.8 & 4.9 & 5.1 & 5.2 & 5.4 & 4.9 & 5.0 & 4.8 & 4.9 & 4.8 & 4.8 \\ 4.7 & 4.5 & 4.3 & 3.9 & 3.8 & 3.6 & 3.8 & 3.8 & 3.7 & 3.7 & 3.6 & 3.6 & 3.6 \\ 5.1 & 5.6 & 5.6 & 5.6 & 5.6 & 5.5 & 5.6 & 4.7 & 4.7 & 5.0 & 4.8 & 4.9 & 4.6 \\ 2.4 & 25 & 2.5 & 2.4 & 2.4 & 2.4 & 2.5 & 2.3 & 2.4 & 2.3 & 2.3 & 2.4 & 2.3\end{array}$

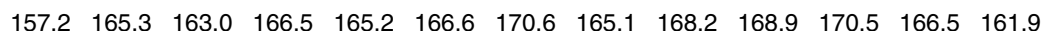

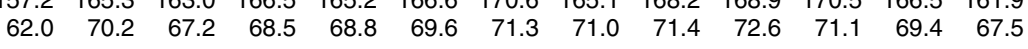

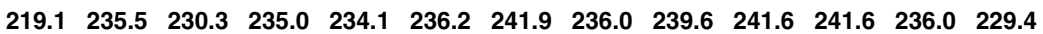

\section{Reallocated use of energy}

Energy industry electricity tranformation losses and distribution losses and allocated to final consumer

Agriculture

Mining and quarying

Manufacturing

Electricity, gas and water supply

Construction

Wholesale and retail trade

Transport and communication

Other business services

Public administration

Education, health and social work

Other services

Total non-household

Households

Total energy consumption of primary fuels and equivalents

Energy from renewable sources ${ }^{2}$ Percentage from renewable sources

$\begin{array}{lrrrrrrrrrrrrr}\text { JKQS } & 3.3 & 3.4 & 3.3 & 3.3 & 3.3 & 3.2 & 3.1 & 3.1 & 3.2 & 3.1 & 3.1 & 3.1 & 2.9 \\ \text { JKQT } & 5.2 & 6.7 & 6.8 & 7.3 & 7.1 & 7.5 & 8.5 & 8.3 & 8.4 & 8.4 & 8.3 & 8.0 & 7.7 \\ \text { JKQU } & 63.2 & 62.3 & 61.7 & 61.0 & 60.6 & 59.7 & 58.2 & 56.9 & 58.1 & 56.4 & 57.1 & 55.5 & 53.4 \\ \text { JKQV } & 6.7 & 6.8 & 5.2 & 7.1 & 7.2 & 7.7 & 8.5 & 7.6 & 6.6 & 7.5 & 7.3 & 7.5 & 7.4 \\ \text { JKQW } & 3.1 & 3.6 & 3.6 & 3.6 & 3.5 & 3.5 & 3.5 & 3.6 & 3.6 & 3.7 & 3.9 & 3.8 & 3.9 \\ \text { JKQX } & 11.2 & 12.7 & 13.1 & 13.2 & 13.5 & 13.8 & 13.8 & 13.6 & 13.9 & 14.3 & 14.2 & 14.0 & 14.0 \\ \text { JKQY } & 23.7 & 28.6 & 29.1 & 30.4 & 30.2 & 31.2 & 32.9 & 32.8 & 34.2 & 35.7 & 37.0 & 34.6 & 34.3 \\ \text { JKQZ } & 7.7 & 8.2 & 8.4 & 8.6 & 8.8 & 9.2 & 9.5 & 8.8 & 9.0 & 8.7 & 8.8 & 8.8 & 8.6 \\ \text { JKRA } & 6.4 & 5.4 & 5.1 & 4.5 & 4.2 & 4.1 & 4.3 & 4.1 & 4.3 & 4.2 & 4.1 & 4.0 & 3.9 \\ \text { JKRB } & 7.3 & 7.9 & 7.8 & 7.9 & 7.8 & 7.5 & 7.7 & 6.7 & 6.5 & 6.8 & 6.7 & 6.8 & 6.5 \\ \text { JKRC } & 3.4 & 3.5 & 3.4 & 3.3 & 3.2 & 3.2 & 3.4 & 3.2 & 3.4 & 3.3 & 3.3 & 3.3 & 3.2\end{array}$

$\begin{array}{lllllllllllll}141.4 & 149.0 & 147.6 & 150.0 & 149.4 & 150.5 & 153.5 & 148.7 & 151.2 & 152.2 & 153.6 & 149.6 & 145.8\end{array}$ $\begin{array}{lllllllllllll}77.7 & 86.5 & 82.7 & 85.1 & 84.7 & 85.6 & 88.4 & 87.4 & 88.4 & 89.4 & 88.0 & 86.4 & 83.6\end{array}$

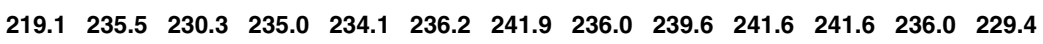

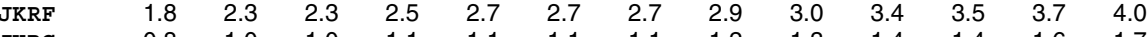

1 Nuclear power, hydroelectric power and imports of electricty.

2 Renewable sources include solar power and energy from wind, wave and

Source: AEA Energy \& Environment, DECC, ONS

tide, hydroelectricity, wood, straw and sewage gas. Landfill gas and munici-

pal solid waste combustion have also been included within this definition. 


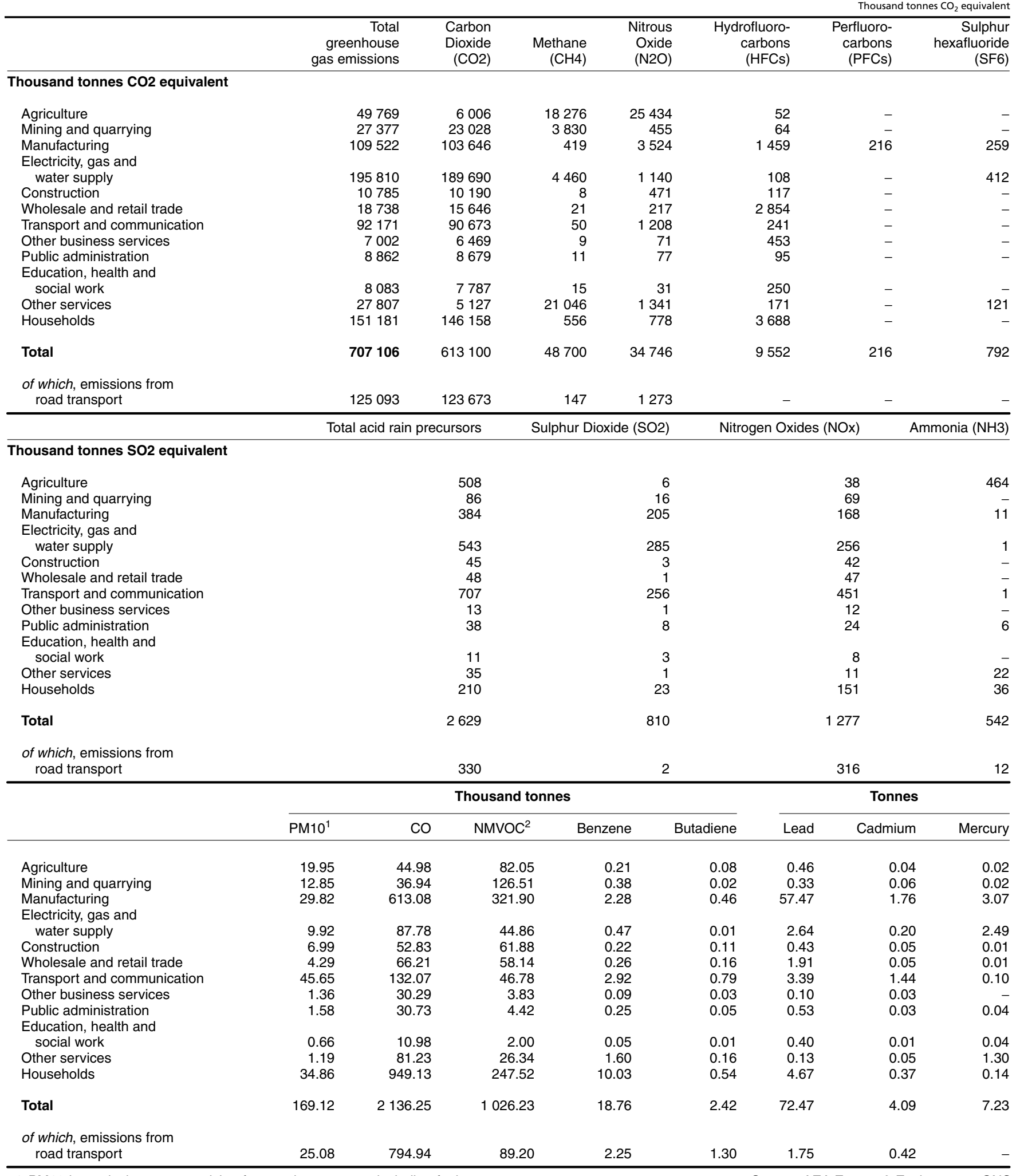

1 PM10 is particulate matter arising from various sources including fuel comSource: AEA Energy \& Environment, ONS

bustion quarrying and construction, and formation of 'secondary' particles

in the atmosphere from reactions involving other pollutants sulphur dioxide, nitrogen oxides, ammonia and NMVOCs

2 Non-methane Volatile Compounds, including benzene and 1,3-butadiene. 


\begin{tabular}{|c|c|c|c|c|c|c|c|c|c|c|}
\hline & & 1990 & 2000 & 2001 & 2002 & 2003 & 2004 & 2005 & 2006 & 2007 \\
\hline \multicolumn{11}{|l|}{ Thousand tonnes $\mathrm{CO} 2$ equivalent } \\
\hline \multicolumn{11}{|l|}{ Greenhouse gases - CO2,CH4,N2O,HFC,PFCs and SF6 ${ }^{1}$} \\
\hline Agriculture & JKRH & 62389 & 57034 & 54016 & 54198 & 53805 & 53549 & 52518 & 51306 & 49769 \\
\hline Mining and quarrying & JKRJ & 40826 & 34352 & 34660 & 34028 & 32688 & 31341 & 30269 & 27220 & 27377 \\
\hline Manufacturing & JKRK & 173348 & 131468 & 126201 & 117911 & 119113 & 116473 & 116714 & 111850 & 109522 \\
\hline Electricity, gas and water supply & JKRL & 216941 & 174782 & 186722 & 181709 & 189661 & 190000 & 191352 & 199676 & 195810 \\
\hline Construction & JKRM & 8573 & 9547 & 9594 & 9743 & 9832 & 10155 & 10523 & 10518 & 10785 \\
\hline Wholesale and retail trade & JKRN & 14691 & 20761 & 20091 & 19610 & 19655 & 20185 & 19326 & 18531 & 18738 \\
\hline Transport and communication & JKRO & 64196 & 83530 & 87667 & 88374 & 91640 & 96647 & 99766 & 92822 & 92171 \\
\hline Other business services & JKRP & 6920 & 7606 & 7919 & 6832 & 7047 & 6877 & 7015 & 6881 & 7002 \\
\hline Public administration & JKRQ & 10604 & 8684 & 9101 & 9250 & 8580 & 8732 & 8575 & 8392 & 8862 \\
\hline Education, health and social work & JKRR & 10449 & 10076 & 10031 & 8175 & 8434 & 8985 & 8704 & 8553 & 8083 \\
\hline Other services & JKRS & 58261 & 39138 & 35674 & 32574 & 29699 & 28223 & 28119 & 28079 & 27807 \\
\hline Total non-household & IGK4 & 667197 & 576976 & 581677 & 562404 & 570154 & 571167 & 572882 & 563827 & 555925 \\
\hline Households & JKRT & 142258 & 156494 & 160079 & 159002 & 159402 & 162288 & 158658 & 155273 & 151181 \\
\hline Total greenhouse gas emissions & JKRU & 809456 & 733470 & 741756 & 721406 & 729556 & 733455 & 731541 & 719099 & 707106 \\
\hline of which, road transport emissions from all industries ${ }^{2}$ & JKRV & 111823 & 120563 & 120280 & 122616 & 122368 & 123158 & 123487 & 123841 & 125093 \\
\hline of which, total emissions from water transport industry ${ }^{3}$ & F8ZP & 17010 & 16141 & 20551 & 22280 & 23779 & 27450 & 27301 & 19395 & 17690 \\
\hline \multirow[t]{2}{*}{ of which, total emissions from air transport industry ${ }^{4}$} & F8zQ & 20318 & 37273 & 36754 & 36065 & 37314 & 39518 & 42785 & 43577 & 43502 \\
\hline & & & 20 & 200 & 2002 & 2003 & 2004 & 2005 & 2006 & 2007 \\
\hline
\end{tabular}

Thousand tonnes SO2 equivalent

\section{Acid rain precursor emissions - SO2, $\mathrm{NOx}, \mathrm{NH}^{5}$}

Agriculture

Mining and quarrying

Manufacturing

Electricity, gas and water supply

Construction

Wholesale and retail trade

Transport and communication

Other business services

Public administration

Education, health and social work

Other services

Total non household

Households

Total acid rain precursor emissions

of which, road transport emissions from all industries ${ }^{2} \quad$ JKUM

$\begin{array}{lrrrrrrrrr}\text { JKRW } & 693 & 571 & 562 & 551 & 537 & 544 & 527 & 523 & 508 \\ \text { JKRX } & 98 & 84 & 79 & 77 & 91 & 86 & 89 & 93 & 86 \\ \text { JKRY } & 937 & 471 & 453 & 411 & 404 & 412 & 412 & 397 & 384 \\ \text { JKRZ } & 3273 & 1102 & 1021 & 930 & 950 & 766 & 653 & 641 & 543 \\ \text { JKSA } & 70 & 63 & 61 & 59 & 56 & 54 & 52 & 48 & 45 \\ \text { JKSB } & 86 & 66 & 60 & 59 & 55 & 59 & 55 & 50 & 48 \\ \text { JKSC } & 749 & 707 & 830 & 867 & 908 & 1019 & 1009 & 761 & 707 \\ \text { JKSD } & 34 & 22 & 22 & 18 & 17 & 16 & 15 & 14 & 13 \\ \text { JKSE } & 78 & 48 & 48 & 44 & 36 & 41 & 39 & 40 & 38 \\ \text { JKSF } & 61 & 21 & 19 & 14 & 14 & 14 & 13 & 13 & 11 \\ \text { JKSG } & 66 & 42 & 44 & 40 & 40 & 39 & 38 & 39 & 35 \\ & 6144 & 3197 & 3199 & 3070 & 3108 & 3050 & 2902 & 2620 & 2418 \\ \text { IGK5 } & 639 & 391 & 357 & 321 & 293 & 273 & 245 & 230 & 210 \\ \text { JKUK } & & & & & & & & & \\ & & & & & & & & & \end{array}$

Source: AEA Energy \& Environment, ONS

Carbon dioxide, methane, nitrous oxide, hydrofluorocarbons, perfluorocarbon and sulphur hexafluoride expressed as thousand tonnes of carbon dioxide equivalent.

2 Includes emissions from all road transport sources (eg HGVs, LGVs, cars and motorcycles) across all industries

3 Emissions from water transport industry (Environmental Accounts code 69)

4 Emissions from air transport industry (Environmental Accounts code 70)

5 Sulphur dioxide, nitrogen oxides and ammonia expressed as thousand tonnes of sulphur dioxide equivalent. 
Million tonnes

$\begin{array}{llllllllllllll}1970 & 1975 & 1980 & 1985 & 1990 & 1995 & 2000 & 2001 & 2002 & 2003 & 2004 & 2005 & 2006 & 2007\end{array}$

\section{Domestic extraction}

Biomass

Agricultural harvest

Timber

Animal grazing

Fish

Total biomass

Minerals
Ores
Clay
Other industrial minerals
Sand and gravel
Crushed stone
Total minerals
Fossil fuels
Coal
Natural gas
Crude oil

Total fossil fuels

Total domestic extraction

\section{Imports \\ Biomass \\ Minerals \\ Fossil fuels \\ Other products}

Total imports

\section{Exports \\ Biomass \\ Minerals \\ Fossil fuels \\ Other products}

Total exports

Domestic Material Consumption

(domestic extraction + imports - exports)

of which

Biomass

Minerals

Fossil fuels
JKUN

JKUO

JKUP

JKUQ

JKUR

JKUS

JKUT

JKUU

JKUV

JKUW

JKUX

JKUY

JKUZ

JKVB

JKVC

JKVD

JKVE

JKVF
JKVG

JKVH

JKVI

JKVJ

JKVK

JKVL

JKVM

JKVU

G9A8

G9A9

\begin{tabular}{rrrrrrrrrrrrrr}
38 & 33 & 30 & 31 & 38 & 40 & 42 & 46 & 47 & 49 & 50 & 50 & 50 & 50 \\
30 & 32 & 24 & 34 & 41 & 50 & 51 & 54 & 55 & 55 & 60 & 58 & 59 & 63 \\
123 & 111 & 74 & 76 & 89 & 73 & 83 & 99 & 95 & 102 & 127 & 137 & 148 & 146 \\
6 & 7 & 14 & 15 & 19 & 23 & 34 & 34 & 32 & 34 & 36 & 35 & 35 & 37 \\
\hline $\mathbf{1 9 7}$ & $\mathbf{1 8 4}$ & $\mathbf{1 4 1}$ & $\mathbf{1 5 7}$ & $\mathbf{1 8 7}$ & $\mathbf{1 8 8}$ & $\mathbf{2 1 0}$ & $\mathbf{2 3 2}$ & $\mathbf{2 2 8}$ & $\mathbf{2 4 0}$ & $\mathbf{2 7 3}$ & $\mathbf{2 8 0}$ & $\mathbf{2 9 2}$ & $\mathbf{2 9 6}$ \\
\hline
\end{tabular}

\begin{tabular}{rrrrrrrrrrrrrr}
3 & 5 & 8 & 11 & 13 & 15 & 17 & 13 & 15 & 19 & 18 & 19 & 20 & 20 \\
17 & 20 & 26 & 22 & 25 & 39 & 44 & 43 & 42 & 44 & 48 & 48 & 50 & 50 \\
23 & 19 & 60 & 102 & 67 & 103 & 115 & 118 & 120 & 104 & 98 & 88 & 83 & 80 \\
5 & 7 & 8 & 11 & 12 & 17 & 21 & 21 & 20 & 21 & 21 & 21 & 21 & 22 \\
\hline $\mathbf{4 7}$ & $\mathbf{5 1}$ & $\mathbf{1 0 1}$ & $\mathbf{1 4 6}$ & $\mathbf{1 1 7}$ & $\mathbf{1 7 3}$ & $\mathbf{1 9 8}$ & $\mathbf{1 9 4}$ & $\mathbf{1 9 7}$ & $\mathbf{1 8 9}$ & $\mathbf{1 8 5}$ & $\mathbf{1 7 7}$ & $\mathbf{1 7 4}$ & $\mathbf{1 7 3}$ \\
\hline
\end{tabular}

$\begin{array}{llllllllllllll}753 & 758 & 704 & 677 & 772 & 703 & 686 & 701 & 677 & 677 & 706 & 687 & 680 & 683\end{array}$

$\begin{array}{llllllllllllll}131 & 119 & 123 & 120 & 125 & 126 & 127 & 130 & 134 & 130 & 133 & 131 & 128 & 125 \\ 355 & 361 & 296 & 319 & 389 & 346 & 312 & 322 & 307 & 298 & 312 & 300 & 299 & 312\end{array}$
Indirect flows

From domestic extraction (excl soil erosion) ${ }^{2}$ JKVN Of which;

Unused biomass

Fossil fuels

Minerals and ores

Soil excavation and dredging

From production of raw materials

and semi-natural products imported

\begin{tabular}{rrrrrrrrrrrrrr}
149 & 129 & 130 & 94 & 94 & 53 & 31 & 32 & 30 & 28 & 25 & 20 & 19 & 17 \\
17 & 54 & 55 & 37 & 42 & 71 & 108 & 106 & 104 & 103 & 96 & 88 & 80 & 72 \\
- & 2 & 80 & 128 & 92 & 130 & 126 & 117 & 116 & 106 & 95 & 85 & 76 & 77 \\
\hline 166 & 184 & 266 & 259 & 228 & 254 & 266 & 254 & 250 & 237 & 217 & 193 & 175 & 166 \\
\hline & & & & & & & & & & & & & \\
$\mathbf{6 0 3}$ & $\mathbf{6 2 5}$ & $\mathbf{6 6 4}$ & $\mathbf{6 6 5}$ & $\mathbf{7 0 2}$ & $\mathbf{6 8 8}$ & $\mathbf{6 7 3}$ & $\mathbf{6 6 3}$ & $\mathbf{6 4 5}$ & $\mathbf{6 2 5}$ & $\mathbf{6 1 8}$ & $\mathbf{5 8 4}$ & $\mathbf{5 6 3}$ & $\mathbf{5 6 0}$
\end{tabular}

Other indicators

Physical trade balance (imports - exports) ${ }^{3} \quad$ DZ 76

Direct Material Input

(domestic extraction + imports)

JKVT

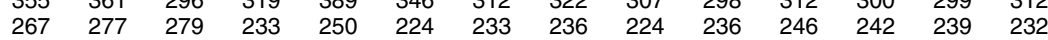

Total Material Requirement

(direct material input + indirect flows) $\begin{array}{llllllllllllll}577 & 577 & 635 & 627 & 693 & 633 & 566 & 572 & 564 & 549 & 547 & 519 & 487 & 488\end{array}$

$\begin{array}{rrrrrrrrrrrrrr}25 & 23 & 32 & 35 & 37 & 37 & 40 & 35 & 40 & 38 & 39 & 38 & 36 & 34\end{array}$

$\begin{array}{rlllllllllllll}169 & 204 & 289 & 274 & 309 & 276 & 230 & 241 & 225 & 209 & 204 & 178 & 149 & 151\end{array}$

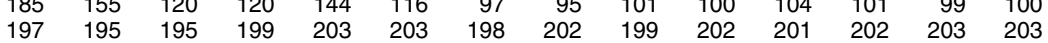

$\begin{array}{llllllllllllll}394 & 395 & 368 & 423 & 457 & 527 & 614 & 711 & 648 & 671 & 692 & 752 & 792 & 761\end{array}$
The earliest revision is represented by a cross

1 Components may not sum to totals due to rounding

2 Indirect flows from domestic extraction relate to unused material which is

moved during extraction, such as overburden from mining and quarrying.

3 A positive physical trade balance indicates a net import of material into the

UK. This calculation of the PTB differs from the National Accounts 


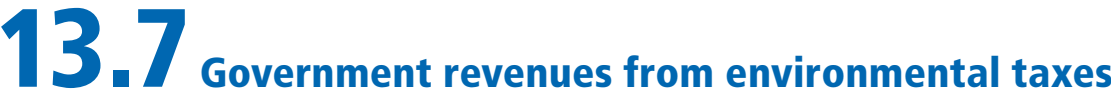

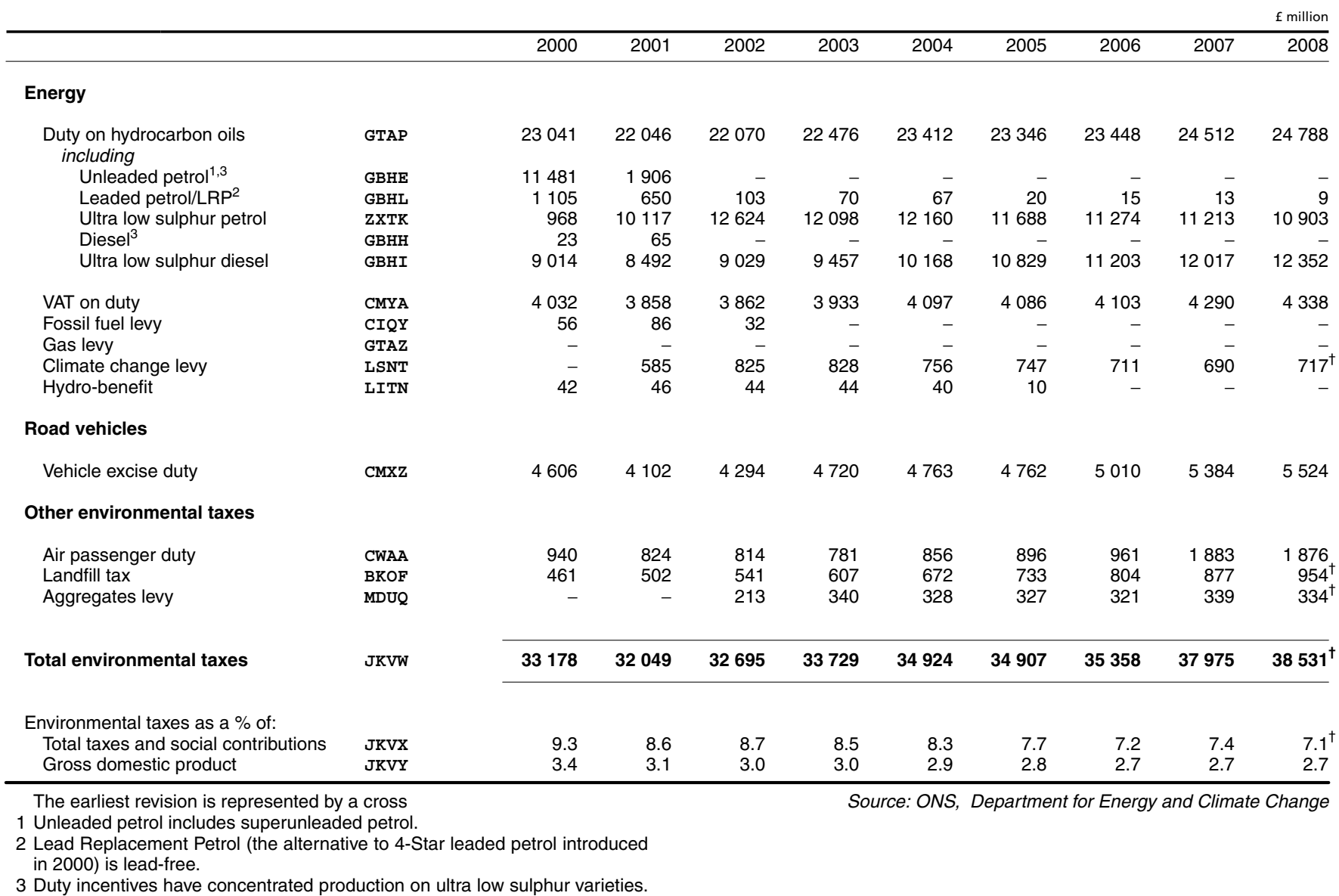

\section{Environmental taxes breakdown by 13 industries $13.8_{2007}$}

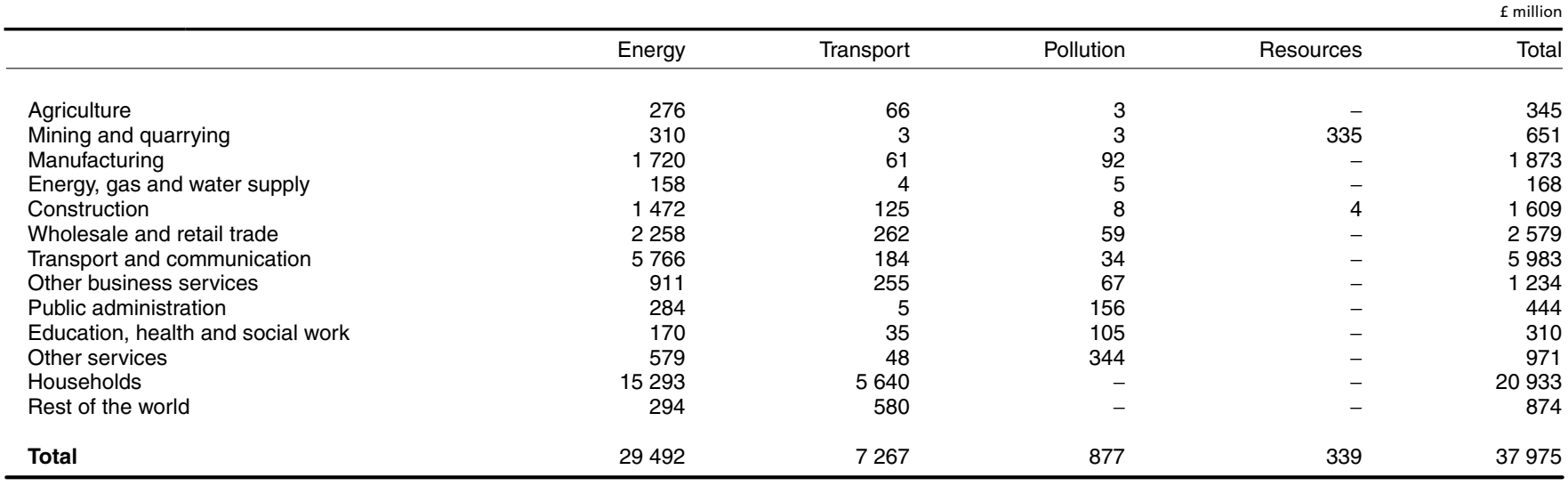

Components may not sum to totals due to rounding 


\section{Environmental protection expenditure in specified industries} 2006

\begin{tabular}{|c|c|c|c|c|c|c|c|}
\hline & $\begin{array}{l}\text { Protection } \\
\text { of ambient air } \\
\text { and climate }\end{array}$ & $\begin{array}{r}\text { Waste } \\
\text { water } \\
\text { management }\end{array}$ & $\begin{array}{r}\text { Waste } \\
\text { management }\end{array}$ & $\begin{array}{r}\text { Protection } \\
\text { of bio-diversity } \\
\text { and landscape }\end{array}$ & $\begin{array}{r}\text { Other } \\
\text { abatement } \\
\text { activities }\end{array}$ & $\begin{array}{r}\text { Research and } \\
\text { development } \\
\text { education and } \\
\text { adminstration }\end{array}$ & $\begin{array}{r}\text { Total } \\
\text { environmental } \\
\text { expenditure }\end{array}$ \\
\hline Mining and quarrying & 27 & 133 & 45 & 3 & 25 & 2 & 236 \\
\hline Food, beverages and tobacco products & 14 & 280 & 158 & 2 & 64 & 7 & 525 \\
\hline Textiles, clothing and leather products & 4 & 33 & 24 & - & 6 & 2 & 68 \\
\hline Wood and wood products & 17 & 4 & 34 & - & 7 & 4 & 66 \\
\hline Pulp and paper products, printing and publishing & 19 & 30 & 106 & - & 17 & 3 & 176 \\
\hline Coke, petroleum and nuclear fuel & 27 & 19 & 6 & - & 53 & 1 & 106 \\
\hline Chemicals and man made fibres & 54 & 100 & 93 & 1 & 30 & 15 & 293 \\
\hline Rubber and plastic products & 20 & 21 & 67 & - & 36 & 3 & 146 \\
\hline Other non metallic mineral products & 24 & 25 & 57 & 3 & 16 & 3 & 129 \\
\hline Basic metals and metal products & 52 & 107 & 94 & 4 & 73 & 4 & 334 \\
\hline Machinery and equipment & 14 & 33 & 80 & 2 & 53 & 4 & 187 \\
\hline Electrical, medical and optical equipment & 4 & 13 & 24 & - & 9 & 5 & 55 \\
\hline Transport equipment & 27 & 93 & 124 & 1 & 9 & 3 & 257 \\
\hline Other manufacturing & 7 & 17 & 55 & - & 8 & 3 & 89 \\
\hline $\begin{array}{l}\text { Total expenditure in extraction, manufacturing, } \\
\text { energy and water supply industries }\end{array}$ & 830 & 935 & 988 & 50 & 1347 & 80 & 4228 \\
\hline
\end{tabular}

The figures in these tables fall outside the scope of National Statistics.

2 Components may not sum to totals due to rounding.

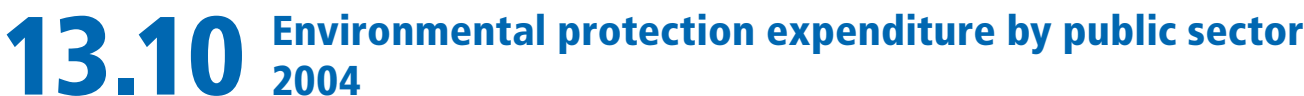

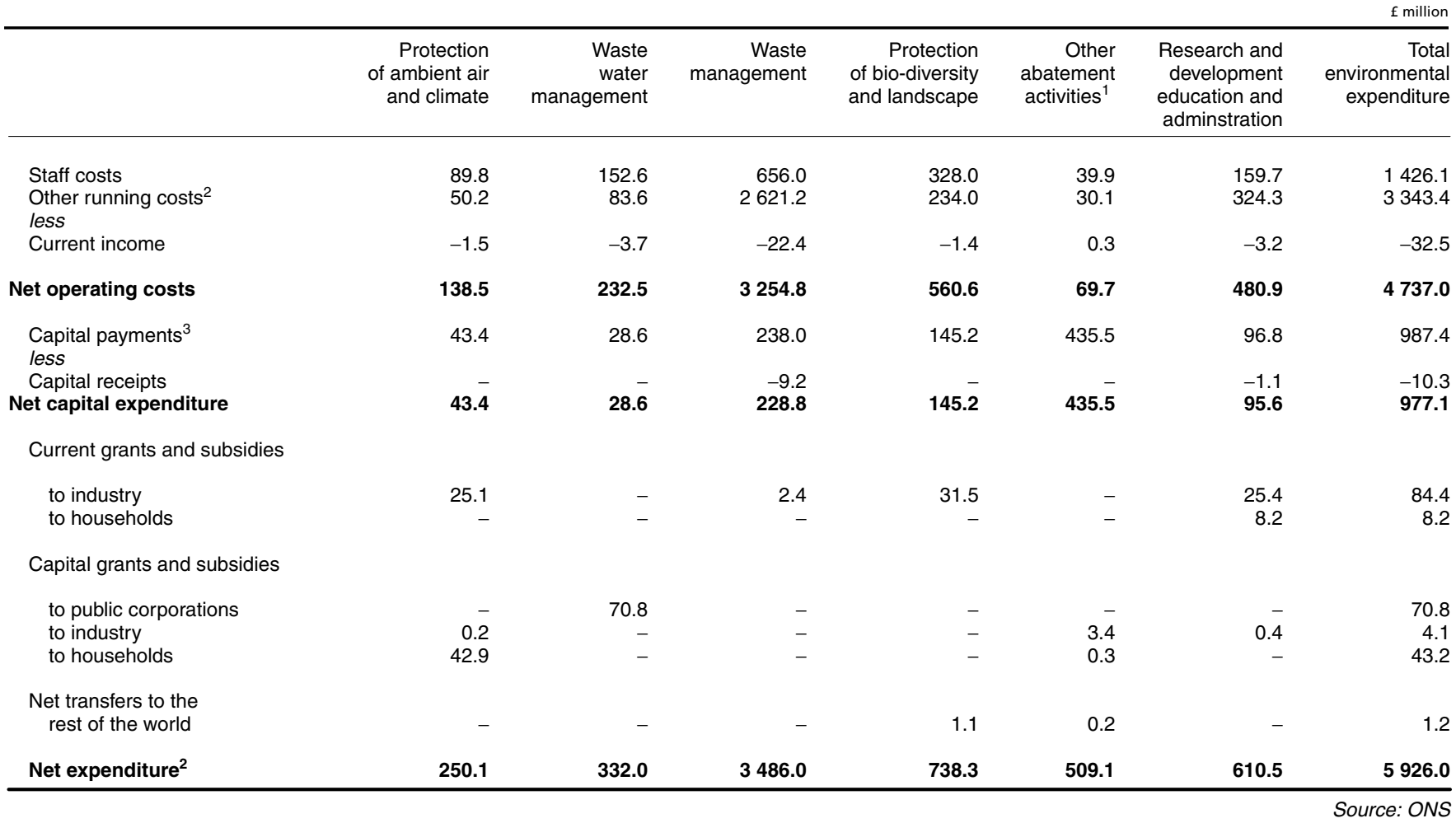

